\title{
Friendship in Cicero: A Pre-Condition for Development
}

\author{
Chidimma Stella Ukaulor \\ Department of Philosophy, Imo State University, Owerri, Nigeria \\ Email: mmaimsu@gmail.com
}

Received 23 October 2014; accepted 24 March 2015; published 27 March 2015

Copyright (C) 2015 by author and Scientific Research Publishing Inc.

This work is licensed under the Creative Commons Attribution International License (CC BY). http://creativecommons.org/licenses/by/4.0/

(c) $\underset{\mathrm{EY}}{\mathrm{i}}$ Open Access

\begin{abstract}
Friendship is one the anthropological and existential concepts bothering the human society. It is a factor seen as common yet powerful. It is a tool for development. When there is friendship, be it among equals, nations, communities, races and religions, there would be peace and love, hence there would be development. This work will therefore make an analysis of the notion of friendship, narrowing it down to the thought of Cicero, targeting the causes, types, as well as the importance of friendship in the contemporary society. It, however, concludes that since we cannot exist alone and learning to resolve conflict is an important function of friendship, families, churches, members of various tribes and nations should therefore adopt cicerone notion of perfect friendship for the growth and development of the society.
\end{abstract}

\section{Keywords}

Friendship, Development, Society, Human Being

\section{Introduction}

From antiquity, it has been a common or general expression to acknowledge someone as our friend in the society; this could be one's best friend, family friend, girlfriend and so on. Friendship is a human condition, rooted in the unchanging human nature and also points to the prevalence of love, care and concern in the human society.

Human beings are not only sentient and rational beings (Homo Sapiens Sapiensis). But they are also social beings (enssocialis), who are neither islands (egosolus) nor exit in isolation but live in a socially constituted society with constant interaction with fellows. This, however, made Martin Heidegger regard man as a being with others (with God, fellow man, animals and inanimate objects); the beingness of each person is fundamentally rooted in the existence of others.

This work makes an exposition of the notion of friendship in Cicero, pointing out the importance of friendship 
in the contemporary society. Friendship is quintessential because where and when there is friendship; there would be peace and unity, hence development, beginning from the family level down to the societal level.

\section{The General Notion of Friendship}

The word friendship simply means the state, or feeling of being friends. In other words, it implies a relationship between people who are not related by blood. Friendship is associated with the Greek word Philia, which means love (mutual love), or affection existing between partners. It also covers any mutual attraction between two human beings outside the family circle and those dear to us (Amaku, 2000).

Friendship involves an openness of each to the other as well as the enlargement of the self. According to Aristotle, the excellent person is related to his friend in the same way as he is related to himself, since a friend is another self and therefore, just as his being is choice; worthy of him, the friends being is choice worthy for him in the same way. Jackie Robinson (2001) explains:

Friendships are fundamentally different from family relationships. They are more egalitarian than relationships with parents... Friendships are based on choice and commitment.

Friendship opens the door to an escape from egoism (the pursue of one own self interest). It is a purely personal matter requiring virtue, yet which runs counter to the universalistic requirement of impartial treatment of all for a friend is someone who is treated differently from others.

A friend could also be a supporter, a helper, an acquaintance, one who is not an enemy or one who encourages as well as one who celebrates and tolerates us. In other words, a friend could be one whom one is comfortable with.

\section{The Notion of Development}

The word Development is a multidimensional word, which implies that it has been defined differently by different people from different disciplines and perspectives. Development can be defined as a gradual growth of something (whether human or animal), so that it becomes more advanced and stronger. It can also be seen as that brings out the potentials as well improve the life of the people which has transformative impact on the state and society. Thus U. D. Anyanwu (2011) explains:

Development means the aggregated effort to improve every element or factor that would enhance the life and nature of persons in any community, small or large. It is social and human center.

This development is homocentric as well as anthropocentric; as such it centers human enhancement and the various facets of the society, rather than the improvement and enhancement of objects, things or inanimate beings. In other words, development aims at regenerating and empowering members of any given society (both skilled both in minds and in hands) rather than neither destroying nor marginalizing them in a way that would affect the society negatively.

\section{Tullius Cicero on Friendship}

Tullius Cicero (106-43BC), a Roman Philosopher cum writer, expressed his views on friendship, in his work called DeAmiticia. He wrote this book on friendship, in memory of his friend, Atticus.

Cicero's notion of friendship is both existential and anthropological; hence, he recognized the necessity of friendship in human existence. Cicero therefore defines friendship as living on closet intimacy and affection. In other words, friendship is the willing of good things to another person for the own sake of him who loves, together with the same will on his part towards you as well as a complete accord on all subject, human and divine, joined with mutual goodwill and affection (Cicero, 1952).

According to Cicero (1952) friendship is a common and natural phenomenon in the animal world, hence, he says:

Turn which way you please, you will find it at hand. It is everywhere, and yet never out of place, never unwelcome. The strength of this feeling you may notice in certain animals. They show such love to their offspring for a certain period and are so beloved by them, that they clearly have a share in this natural, instinctive affection. 
In other words, friendship is the one thing the utility of which everybody with one accord is agreed and without friendship, life is no life, for friendship in any way or another penetrates into the lives of us all.

He went further to explain that what makes life so charming and worth living does not fall on wealth nor on intellectual prowess nor on beauty nor on political prestige but on friendship. Friendship is therefore the noblest and best gifts of the gods to mankind. Except the gift of wisdom, nothing is better than this has been given to man by the immortal gods. He therefore regards friendship as the greatest thing in the world; for there is nothing, which so fits in with our nature or is exactly what we want in prosperity or adversity (Cicero, 1952).

However, mutual good will, affection, likeness, stability, constancy, fidelity, equality, and integrity are the features of friendship. He opines without mutual good will, life would not worth living and therefore offers a significant rule of friendship: do not to let an excessive affection hinder the highest interest for friends.

As regards the causes of friendship, Cicero sees nature is one of the causes of friendship. Nature herself has caused a kind of friendship to exist, though it is one, which lacks some of the elements of permanence. Friendship spring from a natural impulse than a wish to help from an inclination of the heart, combined with a certain instinctive feeling of love rather than from a deliberate calculation of the material advantage it confers... (Cicero, 1952)

Cicero also looks at virtue as another leading factor in the establishment of friendship: the purpose of friendship is for a virtuous life: the clear indication of virtue to which a mind of like character is naturally attracted is the beginning of friendship (Cicero, 1952).

Nature has given us friendship as the handmaid of virtue, not being powerless when isolated to reach the highest objects... those who enjoy in the present or have enjoyed in the past or are destined to enjoy in the future such a partnership as this, must be considered to have secured the most excellent and auspicious combination for reaching natures highest good. This is partnership, I say, which combines moral rectitude, fame, peace, of mind (Cicero, 1952).

Self sufficiency is another cause of friendship says Cicero. Partners enjoy friendship when both are self sufficient, for none has the intention of exploiting the other or depending on the other for life necessities: for when a man is confidence in himself is greatest, when he is so fortified by virtue and wisdom as to want nothing and to feel absolutely self dependent; it is then that he is most conspicuous for seeking out and keeping up friendship (Cicero, 1952).

Furthermore, he outlined the different types of friendship, namely:

a) Friendship Based on Profit

b) Friendship Based on Pleasure

c) Friendship Based on Perfection

a) Friendship Based on Profit

According to Cicero, this type of friendship is not the ideal type of friendship, because it is exploitative in nature, material based as well as profit oriented. To him, most people not only recognize nothing as good in our life unless it is profitable, but look upon friend as so much stock, caring most for those by whom they are to make most profit.

To him therefore, they never posses that most beautiful and most spontaneous friendship, which must be sought solely for itself without any ulterior object (Cicero, 1952).

b) Friendship Based on Pleasure (Hedonistic Friendship)

This type of friendship according to Cicero is based on Pleasure. He condemns it as bestial in character and the worst of them all. It also does not last and it expires once what sustains it dies; which could be sex, drink and so on. It therefore uses a human as a means (it reifies the human being, as an "it") to an end rather than as an end in itself (a thou). It can also be called hedonistic friendship.

c) Perfect Friendship

This is the best type of friendship for it exists among good men and the good refers to those whose action and lives leave no question as to their honour, purity, equity and liberty; those who are free from greed, lust, and violence; and who have courage of their convictions. To the best of human ability, they follow nature as the most perfect guide to a good life (Cicero, 1952).

This type also exist among mature and disciplined men: This sort of friendship is rare: and indeed excellent things are rare and nothing in the world is so hard to find as a thing entirely and incompletely perfect of its kind. The good men have respect for themselves, for without respect, friendship has lost its brightest jewel.

It is also a friendship based on virtue (justice, temperance, fortitude and prudence), the virtuous man is not 
controlled by passion. Another law for virtuous friendship: we should ask from friends and do for friends only what is good. The friendship of good men demands that the characters of both are stainless. There must be harmony of interests, purpose and aim without exception.

He therefore gives another cardinal rule of friendship: neither asks nor consents to do what is wrong, or plea for a discreditable one, and not to be admitted for a moment. Friendship should never be put to bad use, especially that of disloyalty to the republic.

Perfect friendship can hardly exist without mutual loyalty, shown in simplicity, which is a social disposition and of a sympathetic nature - the ability of being moved by what moves a friend. It therefore demands trust and knowledge, not based on is material gain but for the feeling of friendship itself.

\section{Cicerones Friendship and Its Relevance}

We have seen Cicero's analysis of friendship. The ultimate questions are: what types of a friendship exist in/ around us? What type of friends do we have? Can there be mutual friendship?

In those days, a friend is someone who is always welcomed in one's family. A good friend shares his or her friends secrets, helps another with domestic chores (washing of plates, clothes, fetching of firewood, fetching water from the stream and so on), running errand, cries when his or her friend is crying and as well laughs or rejoices too; hence the Igbo saying ezienyikanwanne (a good friend that is better than a brother), a friend in need is a friend in need, etc. The rate of betray, envy, immorality were not on the increase.

In this dispensation, the times are not so good and friendship that exists between people and nations are not as sweet as it tends to be, despites that without friendship, the society would be chaotic and full of hatred. Hence Eva Peron (2001) explains:

Through friendship, and interaction, people learn how to solve problems in relationships, they learn how to put themselves in another person's place and they see models of various kinds of behavior.

This therefore implies that friendship is used in solving problems; as such its importance cannot be underestimated. In Nigeria for instance, there are societal issues and challenges such as tribalism, terrorism, statism, kidnapping, human trafficking etc. these challenges can be curbed through perfect friendship.

However, friendship involves doing things together as well as mutual give and take. In other words, the strongest friendships involve equal commitment, intimacy, loyalty and sharing. Marian Anderson (2001) explains further:

The most important feature of friendship is doing things together, liking and caring for each other, sharing and helping one another...

In the society, when people, neighbours, friends, states, religions, communities and nations start caring and helping one another, there would be no societal problem, no kidnapping, no religious wars and all that. But the most ironical aspect is that most friendship is associated with hatred, wickedness, cheating, jealousy and other immoralities. Man is now a wolf to his fellow man (homo hominilipus) be it in the work place, school, church and so on. we have heard or even seen where a friend out of jealously that her friend is getting married before her, goes to poison her friend, snatch away her husband-to-be, or even goes to the extent of visiting evil places just to ensure that her friend's life or happiness is terminated. This is to say that false or fake friendship is the inn thing now. I am not saying that there are no men or women of virtue who can be trusted as friends but my argument is that most of them are fake, whose friendships are based on material gains or pleasure. It has also been discovered and one would agree with this Igbo adage "onye di mman'azu"? It is not a matter or question of who is a real friend, but it is a matter of who stays real behind your back? It is only trusted and good friend can protect one behind one's back (in rare cases). Once one is gone, no matter how good one is, someone (his/her friend) is there to criticize the person.

The alarming rate of enyigburuenyiya (a friend who betrays his/her friend as the case may be) has made people skeptical about friendship. Some people as a result of all the evil experiences associated with friends, do not believe in friendship, some are scared, others even scold or flog their children, wards, relatives when they visit their friends or talk about friendship. This, however, reminds of a saying 'friends fakeness and bullshit are the main reason I like to be alone at times. Should we because of these experiences live in isolation?

Friendship is also another medium for solving societal problems. In other words, learning to resolve conflict 
is an important function of friendship and these problems are centered on man, the centre of dignity. Unlawful shedding of blood, neo-slavery, among others defiles the dignity of man. All these issues can be resolved; if there is love and peace. Peace and love can therefore be possible if there is mutual friendship.

Friendship provides a safe place to venture opinions, admit weaknesses and get help in coping with problems. This is only possible with the use of reason. E. E. Amaku (2014) explains:

Nature has equipped man with the powers of reasoning, volition, and moral sense, which constitute the natural basis of mans personal dignity, person freedom and moral responsibility.

Since all that glitters is not gold; we can hardly get a friend who is indeed a friend when you are in need. We always have friends who love us when the going is good but when the going becomes bad, most of them will always disappear or give flimsy excuses for not being there. This is also in line with a saying that failure/challenges have no friend but success even has many friends and relatives everywhere. We should therefore be thorough in choosing friends.

\section{Conclusion}

From the above analysis and explanation, we have seen that friendship is solely a human activity despite that every human is unique and autonomous, yet he or she is incomplete without others.

Friendship is also it rooted in intimacy, affection, harmony, mutual goodwill, choice and equality. Since no human person is not an island, a beast nor a god, friendship on itself is a necessity, not a contingency; therefore one has to be critical and very careful while choosing a friend or friends, when this is done, there is peace, which fosters the development of any human society.

\section{References}

Amaku, E. E. B. (2014). The Problematic of Human Dignity in Africa. Owerri: Living Flame.

Amaku, E. E. B. (2000). Philosophical Approaches to Friendship. Owerri: Austus.

Anderson, M. (2001). Psychosocial Development in Middle Childhood Human Development. In D. E. Papalia et al. (Eds.), (8th ed., p. 388). New York: McGraw Hills.

Anyanwu, U. D. (2011). For the Sake of History, Culture and Development. Inaugural Lecture Series No. 3. Owerri: Imo State University.

Cicero, T. (1952). Cicero on Friendship in World Book of Western World, Vol. 20 ed., Mortimer J. Adler. New York: Encyclopedia Britannica Inc.

Peron, E. E. (2001). Psychosocial Development in Early Childhood Human Development. In D. E. Papalia et al. (Eds.), (8th ed., p. 313). New York: McGraw Hills.

Robinson, J. (2001). Psychosocial Development in Adolescence in Human Development. In D. E. Papalia et al. (Eds.), (8th eds.). New York: McGraw Hills. 